\title{
ジプロピニルトリメチルアンチモン $(\mathrm{V})$ と酸塩化物の パラジウム触媒反応
}

\author{
（1986 年 10 月 31 日受理）
}

山本陽介・沖中隆明・中谷雅行・秋葉欣哉*

\section{1 粕言}

第三周期以降の典型元素は容易に原子価を払張できる (hypervalency）といら特徽を有する1)。著者らはこれまで硫黄を中心と した化合物に扰いて原子価据張能に起因する結合交換2)やスルフ ラン形成わなどの新規な性質が発現することを報告してきた。さ らにこれらの配位数抢よび原子価の変動に関する研究が炭素化合 物の化学と遷移金属の化学の橋渡しとして位監づけられるとの観 点に立ち，より金属性が高くかつ小さい結合エネルギーをるつ五 配位有機アンチモン化合物の合成と反応汪する研究を開始し た。これらの化合物は水などに対する不安定性のために例は少な いがおるに三方両錐構造をとることが知られている4)。この場合 アピカル結合が hypervalent 結合 (三中心四電子結合) を形成し ておりェクアトリアル結合より長くて弱いが，そのようなアピカ ル結合の弱さに着目して反応性の研究を行なった例はほとんぞな い。そこで著者らはまず三方両錐構造であることがX線偁造解析 により確認されているジプロピニルトリメチルフンチモン $(\mathrm{V})$ 〔1 古を取り上げた。本論文では〔1]と酸塩化物とのパラジウ ム触媒存在下での反応について報告する。

\section{2 実験}

ジプロピニルトリメチルアンチモン(V)[1]は文献の方法 ${ }^{5)}$ にしたがいトリメチルアンチモンジクロリドとプロピニルリチウ ムから合成し昇華精製を行なった。収率 $80 \%$, 昇華温度 $70^{\circ} \mathrm{C} /$ $0.3 \mathrm{mmHg}_{\circ}{ }^{1} \mathrm{H}-\mathrm{NMR}\left(\mathrm{C}_{6} \mathrm{D}_{6}\right) \delta: 1.55(\mathrm{~s}, 9 \mathrm{H}), 1.63(\mathrm{~s}, 6 \mathrm{H}) 。$ [1] は空気中ですみやかに分解してトリメチルフンチモンオキ シドとプロピンを生成する。 ${ }^{1} \mathrm{H}-\mathrm{NMR}\left(\mathrm{CD}_{3} \mathrm{OD}\right) \delta: 1.52(\mathrm{~s})$ 。

広島大学理学部化学科, 730 広島市中区東千田町

1) J. C. Martin, Science, 221, 509(1983) ; R. R. Holmes, Acc. Chem. Res., 12, 257(1979).

2) K-y. Akiba, T. Kobayashi, S. Arai, J. Am. Chem. Soc., 101, 5857(1979) ; Y. Yamamoto, K-y. Akiba, ibid., 106, 2713(1984) ; K-y. Akiba, K. Kashiwagi, Y. Ohyama, Y. Yamamoto, K. Ohkata, ibid., 107, 2721 (1985).

3) K-y. Akiba, K. Takee, K. Ohkata, F. Iwasaki, ibid., 105, 6965(1983) ; K-y. Akiba, K. Takee, Y.Shimizu, K. Ohkata, ibid., 108, 6320(1986).

4) M. Wieber, "Gmelin Handbook of Inorganic Chemistry Sb Part I" p. 16, Springer-Verlag, Berlin(1981).

5) N. Tempel, W. Schwarz, J. Weidlein, J. Organometal. Chem., 154, 21(1978).
$\mathrm{Pd}\left(\mathrm{PPh}_{3}\right)_{4}[2]^{6)}$ および $\mathrm{PhCH}_{2} \mathrm{PdCl}\left(\mathrm{PPh}_{3}\right)_{2}[3]^{7)}$ は文献の方 法にしたがってそれぞれ $\mathrm{PdCl}_{2}$ および〔2〕から合成した。 ${ }^{1} \mathrm{H}-$ $\mathrm{NMR}$ は日立 R-90 HNMR (90 MHz) を用いて测定した。

\section{3 結 果と考察}

\section{1 [1]之酸塩化物の反応}

[1]に対する塩化アセチルや $p$-置換ベンゾイルクロリドの反 応を $\mathrm{C}_{6} \mathrm{D}_{6}$ 溶媒中で ${ }^{1} \mathrm{H}-\mathrm{NMR}$ により追跡した。 $60^{\circ} \mathrm{C} 4$ 日間加熱 したのち，TLC で生成物の単離を試みたが， $p$-クロロベンゾィ ルクロリドの場合にプロピニルケトン〔4b〕が $19 \%$ の収率で得 られたたけけで，その他の場合は生成物は確認できなかった。

\section{2 [1]と $\operatorname{Pd}(0)$ との反応}

そこで Pd を触媒として用いた酸塩化物とのカップリング反応 を起こすことを考えた。まず〔1〕と $\mathrm{Pd}(0)$ の反応をブランク として試みた。〔1]と $\mathrm{Pd}\left(\mathrm{PPh}_{3}\right)_{4}$ 〔2] $\left(0.4\right.$ 当量) を $\mathrm{C}_{6} \mathrm{D}_{6}$ 溶 液として ${ }^{1} \mathrm{H}-\mathrm{NMR}$ 追跡した。10 分後には $\delta 0.5$ に $\mathrm{Me}_{3} \mathrm{Sb}$ に 特徵的な吸収を認め， 5 時間後には $\mathrm{Me}_{3} \mathrm{Sb}$ を含む複雑な混合物 に完全に分解した。同様の還元的脱離反応は $\mathrm{Me}_{3} \mathrm{SbCl}_{2}$ と〔2] (0.4 当量) です確認できたが, この場合は 0.4 当量分の $\mathrm{Me}_{3} \mathrm{Sb}$ に分解した段階で反応は終了した。これは $\mathrm{PdCl}_{2}$ が形成された段 階で触媒として機能しなくなったためと考えられる。これらの実 験事実は，五配位アンチモン化合物は $\operatorname{Pd}(0)$ によりみやかに $\mathrm{Sb}(\mathrm{III})$ 一還元的脱離反応を起こすことを示しており，機構とし ては $\mathrm{Pd}(0) 飞 \mathrm{Sb}(\mathrm{V})$ が酸化的付加して $\mathrm{Me}_{3} \mathrm{Sb}(\mathrm{X})-\mathrm{PdX}$ を 形成し引きつづき $\mathrm{Me}_{3} \mathrm{Sb}$ と $\mathrm{PdX}_{2}$ となるものと考兄られる。

3.3Pd を触媒として用いた場合の [1]と酸塩化物の反応 まず， $\mathrm{Pd}$ 触媒として $\mathrm{Pd}\left(\mathrm{PPh}_{3}\right)_{4}[2], \mathrm{PhCH}_{2} \mathrm{PdCl}\left(\mathrm{PPh}_{3}\right)_{2}$ [3]をそれぞれ 5 モル\%用いて〔1]と塩化ベンゾイル〔5 a]の 反応を $\mathrm{CD}_{3} \mathrm{CN}$ 中で ${ }^{1} \mathrm{H}-\mathrm{NMR}$ により追跡した。どちらの場合も まったく同様のスペクトルが得られ，プロピニルケトン [4a]が 生成した。メチル基と反応したアセトフェノンはまったく確認で きなかっだた応速度は〔3〕を用いた方が速くまた〔3〕の取 り报いがより容易であるため以後〔3]を用いて直換基の效果な どの検討を行なった。その結果を表 1 に示した。〔5 a]との反応 において〔5a〕を 2 当量以上用いると収率が向上している。ま た， ${ }^{1} \mathrm{H}-\mathrm{NMR} て ゙ \mathrm{Me}_{3} \mathrm{Sb}$ が生成していることが観測できるが，そ

6) D. R. Coulson, Inorg. Synth., 13, 121(1972).

7) K. S. Y. Lau, P. K. Wong, J. K. Stille, J. Am. Chem. Soc., 98, 5832(1976). 
Table 1 Reaction of $[1]$ with acid chlorides ( $[5]$ : $\mathrm{RCOCl})$ in the presence of $\mathrm{PhCH}_{2} \mathrm{PdCl}\left(\mathrm{PPh}_{3}\right)_{2}$ $([3])$ in concentrated $\mathrm{CD}_{3} \mathrm{CN}^{a}$ )

\begin{tabular}{ccccc} 
Entry & $\mathrm{R}$ & $\begin{array}{c}\text { Molar ratio } \\
{[5]:[1]}\end{array}$ & {$[\overbrace{4]}^{\text {Yield }} \underbrace{(\%)}_{\mathrm{Me}_{3} \mathrm{Sb}^{d)}}$} \\
\hline 1 & $\mathrm{Ph}$ & $1: 1.3$ & $36^{b)}$ & 54 \\
2 & $\mathrm{Ph}$ & $2.3: 1$ & $113^{c)}$ & 8 \\
3 & $\mathrm{EtO}_{2} \mathrm{CCH}_{2} \mathrm{CH}_{2}$ & $2.1: 1$ & $50^{c)}$ & 25 \\
4 & $\mathrm{Me}_{2} \mathrm{CHCH}_{2}$ & $2.5: 1$ & 0 & 85
\end{tabular}

a) $1 \sim 1.5$ molar solution in $\mathrm{CD}_{3} \mathrm{CN}$ in the presence of $1 \sim 2 \mathrm{~mol} \%$ of $\mathrm{Pd}$.

b) Based on [5].

c) Based on [1].

d) Based on [1] (NMR yield).

Table 2 Reaction of [1] with $p$-substituted benzoyl chlorides [5] $\left(p-\mathrm{RC}_{6} \mathrm{H}_{4} \mathrm{COCl}\right)$ in the presence of [ 3$]$ in diluted $\mathrm{C}_{6} \mathrm{D}_{6}{ }^{a}$ )

\begin{tabular}{|c|c|c|c|c|}
\hline \multirow{2}{*}{ Entry } & \multirow{2}{*}{$\mathrm{R}$} & Molar ratio & \multicolumn{2}{|c|}{ Yield(\%) } \\
\hline & & {$[5]:[1]$} & {$[4]^{b)}$} & $\mathrm{Me}_{3} \mathrm{Sb}^{\mathrm{c}}$ \\
\hline 1 & $\mathrm{Me}$ & $1.9: 1$ & 49 & 28 \\
\hline 2 & $\mathrm{MeO}$ & $1.2: 1$ & 53 & 21 \\
\hline 3 & $\mathrm{Cl}$ & $2.0: 1$ & 61 & 17 \\
\hline 4 & $\mathrm{MeO}_{2} \mathrm{C}$ & $2.0: 1$ & 80 & 0 \\
\hline
\end{tabular}

a) $0.15 \sim 0.30$ molar solution in $\mathrm{C}_{6} \mathrm{D}_{6}$ in the presence of $2 \mathrm{~mol} \%$ of $\mathrm{Pd}$.

b) Based on [1].

c) Based on [1] (NMR yield).

の NMR からの収率は単離したプロピニルケトン〔4]の収率と ほぼ反比例していることがわかる。 $\mathrm{Me}_{3} \mathrm{Sb}$ ととも生成してい るはずの $\mathrm{MeC} \equiv \mathrm{C}-\mathrm{C} \equiv \mathrm{CMe}$ はその揮発性のため単離確認はできな かったが，〔4]と $\mathrm{Me}_{3} \mathrm{Sb}$ の生成は競争反応になっていると考元 られる。これはベンゼン環の搷換基の効果を明確にするために行
なったやや希薄の $\mathrm{C}_{6} \mathrm{D}_{6}$ 溶液の実験においても明らかである（表 2 )。この場合は希薄溶液のために〔4]の収率が減少し $\mathrm{Me}_{3} \mathrm{Sb}$ の生成が增加しているが，置換基が電子求引的になるほど〔4〕 の生成が有利になっていることがわかる。これらの実験事実と前 項の $\mathrm{Pd}(0)$ にる[1]の還元的脱離の結果を考市あわせると, つぎのよらな機構が考えられる。触媒として〔2]と〔3]を用 いた場合にほぼ同様の結果が得られることから $\mathrm{Pd}(0)$ が触媒種 と考えられ〔3] からは $\mathrm{PhCH}_{2} \mathrm{PdC} \equiv \mathrm{CMe}\left(\mathrm{PPh}_{3}\right)_{2}$ を経て $\mathrm{Pd}$. $\left(\mathrm{PPh}_{3}\right)_{2}$ が生成するものと考えられる。これは $\mathrm{Pd}\left(\mathrm{PPh}_{3}\right)_{4}$ に比 较してより活性であるため, 反応速度が大きいのであろう。この 上らにして生成した $\operatorname{Pd}(0)$ に対し，〔1〕が酸化的付加して $\mathrm{Me}_{3} \mathrm{Sb}(\mathrm{C} \equiv \mathrm{CMe}) \mathrm{PdC} \equiv \mathrm{CMe}[6]$ が生成し，〔6]から ( i ) $\mathrm{Me}_{3} \mathrm{Sb}$ と $\mathrm{MeC} \equiv \mathrm{C}-\mathrm{C} \equiv \mathrm{CMe}$ を形成する $\mathrm{Sb}(\mathrm{V})$ から $\mathrm{Sb}(\mathrm{III})$ 一の還元的 脱離反応之（ii）酸塩化物との反応による $\mathrm{Me}_{3} \mathrm{Sb}(\mathrm{C} \equiv \mathrm{CMe}) \mathrm{Cl}$ [7]と $\mathrm{RC}(\mathrm{O}) \mathrm{C} \equiv \mathrm{CMe}$ [4] の生成が競争しているすのと考壳 られる。このように考点ると電子求引性の高い酸塩化物を用い, 濃厚溶液としたときに〔4]の収率が高いことが説明できる。条 件によっては〔7]がさらに酸塩化物と反応してアルキニルケト ンを与えるため表 1 の Entry 2 のように収率が 100\%を越える場 合もあるものと考兄られる。これらの機倩は通常のスズ化合物と 酸塩化物の $\mathrm{Pd}$ 触媒反応において受け入れられている機構, すな わち酸塩化物が $\mathrm{Pd}(0)$ に酸化的付加したのちスズからのトラン スメタル化が起こるという機構》とは異なっている。これは五配 位アンチモン化合物の hypervalent 結合がエクアトリアル結合よ り反応性に富み，還元的脱離などの反応を起こしやすいことを示 している。これらの高い反応珄に基づいた hypervalentアンチモ ン化合物の熱的還元的脱離反応の検討も行なっており, 近く発表 する予定である9。

8) D. Milstein, J. K. Stille, J. Am. Chem. Soc., 101, 4992(1979).

9) K-y. Akiba, T. Okinaka, M. Nakatani, Y. Yamamoto, Tetrahedron Lett., 28, in press (1987).

\title{
Special Articles on Organic Chemistry of Heteroatoms-Note-
}

\author{
Reaction of Dipropynyltrimethylantimony(V) with Acid \\ Chlorides in the Presence of $\mathrm{Pd}$
Yohsuke Yamamoto, Takaaki Oкinaka, Masayuki Nakatani and Kin-ya AкıвA* \\ Department of Chemistry, Faculty of Science, Hiroshima University ; \\ Higashisenda-machi, Hiroshima-shi 730 Japan
}

In the presence of catalytic amount of palladium $\left(\mathrm{Pd}\left(\mathrm{PPh}_{3}\right)_{4}, \mathrm{PhCH}_{2} \mathrm{PdCl}\left(\mathrm{PPh}_{3}\right)_{2}\right)$, coupling reaction of dipropynyltrimethylantimon'y $(V)[1]$ with acid chlorides took place to give only propynyl ketones [4] without concomitant formation of methyl ketones. An initial step of the coupling reaction may be the oxidative addition of [1] to $\operatorname{Pd}(0)$ at the propynyl-antimony bond. 